Civil Society Development in Ukraine for 2016-2020. Ordinance of the Cabinet of Ministers of Ukraine No. 296-p of May 11, 2017 Government portal. URL : https://www.kmu.gov.ua/ua/npas/249972001 Ukrainian).

On approval of the action plan for 2018 on the implementation of the National Strategy for Promoting Civil Society Development in Ukraine for 2016-2020. Ordinance of the Cabinet of Ministers of Ukraine No. 297-p of May 10, 2018 Legislation of Ukraine. URL: https://zakon2.rada.gov.ua/laws/show/297-2018-

$\% \mathrm{D} 1 \% 80 \#$ n8 (in Ukrainian).

On promoting civil society in Ukraine. Presidential Decree No. 68/2016 of February 26, 2016 Legislation of Ukraine. URL: https://zakon5.rada.gov.ua/ laws/show/68/2016 (in Ukrainian).

Presidential Decree No. 68/2016. On promoting civil society in Ukraine of February 26, 2016 President of Ukraine. The official website. URL: https://www.president.gov.ua/documents/68201619805 (in Ukrainian).

The decision of the Constitutional Court of Ukraine in the case of constitutional submissions of the Ombudsman and 65 deputies of Ukraine regarding the conformity of the provisions of paragraph 5 of the first Article 3, paragraph 3 of the third Article of the Article 45 of the Law of Ukraine "On Prevention of Corruption" paragraph 2 of section II "Final
Provisions" of the Law of Ukraine "On Amendments to Certain Laws of Ukraine on Features of Financial Control of Individual Categories of Officials" No. v003p710-19 of June 6 2019. Legislation of Ukraine. URL: https://zakon.rada.gov.ua/laws/show/v003p71019?lang=uk (in Ukrainian).

"The community organization can now be registered online", E-governance for Accountability and Participation Program 2019. URL: https:// egap.in.ua/novyny/vidteper-hromadsku-orhanizatsiiumozhna-zareiestruvaty-onlain/ (in Ukrainian).

Jarábik B., de Waal T. 2018. "Ukraine Reform Monitor: March 2018" Carnegie Endowment for International Peace. URL: https://carnegieendowment. org/2018/03/27/ukraine-reform-monitor-march-2018pub-75909

"G7 Ambassadors welcome decision on unconstitutionality of e-declaration for anti-corruption activists" Unian, 2019. URL: https://www. unian.info/politics/10579152-g7-ambassadorswelcome-decision-on-unconstitutionality-of-edeclaration-for-anti-corruption-activists.html

"International Reform Conference in Ukraine, Toronto, 2-4 July 2019" Government portal. URL: https://www.kmu.gov.ua/ua/diyalnist/reformi/mizhnaro dni-konferenciyi-z-pitan-reform-v-ukrayini/ mizhnarodna-konferenciya-z-pitan-reform-v-ukrayinitoronto-lipen-2019 (in Ukrainian).

DOI: 10.26565/2220-8089-2019-35-03

УДК 342.815 .1

\author{
Bohdan Tymchyshyn \\ graduate student, \\ V.N. Karazin Kharkiv National University, \\ 4, Svoboda Sq., Kharkiv, 61022, \\ sonicofan@ukr.net, \\ https://orcid.org/0000-0001-7469-7339
}

\title{
TOTAL INCLUSION IN DEMOCRACY AS A PROBLEM OF POLITICAL DEVELOPMENT
}

Having defeated global socialism in the competition, liberalism and democracy proved their superiority. Having freed themselves from obvious external threats, domestic political challenges began to acquire increasing importance. Internal factors mean both the problems of each particular democratic society and the problems of conceptual understanding of liberal democracy in the contemporary context.

It turns out that populism in the last 5 years has become the most dangerous problem in a number of young and mature democracies. The populist rhetoric of politicians is aimed at the part of the electorate that is ignorant and eager to hear quick solutions to complex systemic problems. This is especially dangerous for societies in which a political nation has not yet been formed, which is just beginning to take its first steps towards its own institutionalization and therefore requires the attention and concrete action of responsible civil society.

Exacerbations of the chronic problems of society remain unnoticed by many influential politicians.

(C) Tymchyshyn B., 2019. 
The problem of developing complex solutions to the new challenges of our time, in particular the need to understand what price society pays for the dogmatic faith in the permanent liberalization of the democratic process and the inclusion of various groups, is being solved. The necessity of adapting the structures of liberal democracy to the new conditions of the prevailing modern political reality in order to maintain political security is noted. A proposal is made to look pragmatically at the state of affairs of modern liberalism.

Keywords: liberalism, democracy, universal suffrage, voting right, citizenship, nation-building, national security, populism, instability.

\section{Тимчишин Богдан Володимирович}

студент магістратури,

Харківський національний університет імені В. Н. Каразіна, майдан Свободи, 4, Харків, 61022, sonicofan@ukr.net,

https://orcid.org/0000-0001-7469-7339

\section{ТОТАЛЬНА ІНКЛЮЗИВНІСТЬ В ДЕМОКРАТІЇ ЯК ПРОБЛЕМА ПОЛІТИЧНОГО РОЗВИТКУ}

Перемігши в конкурентній боротьбі глобальний соиіалізм, лібералізм $і$ демократія, довели свою перевагу. Позбувшись очевидних зовнішніх загроз, внутрішньополітичні виклики почали набувати все більшого значення. Під внутрішніми чинниками розуміються як проблеми кожного окремого демократичного суспільства, так і проблеми концептуального розуміння ліберальної демократії в сучасному контексті.

Стверджується, щяо популізм в останні 5 років став найбільш небезпечною проблемою в ряді молодих і сталих демократій. Популістська риторика політиків спрямована на ту частку електорату, якій притаманні невігластво та бажання почути швидкі рімення складних системних проблем. Це особливо небезпечно для суспільств, в яких ще не сформована політична начія, котра тільки починає робити свої перші кроки до власноі інституціоналізації $i$ тому вимагає уваги $i$ конкретних дій з боку відповідального громадянського суспільства.

Загострення хронічних проблем суспільства залишаються поза увагою багатьох впливових політиків, політизачія всього, що раніме належало сфері приватного, поляризація $i$ популізм - жодним чином не впливають на зміцнення ліберальної демократії та однорідності суспільства.

Вирішується завдання вироблення комплексних рішень нових викликів сучасності, зокрема потреби зрозуміти, яку иіну суспільства платять за догматичну віру в перманентність лібералізації демократичного процесу $i$ інклюзії різних груп. Зазначається необхідність адаптації структур ліберальної демократії до нових умов сформованої сучасної політичноі реальності з метою збереження політичної безпеки. Робиться пропозиція прагматично подивитись на стан справ сучасного лібералізму.

Ключові слова: лібералізм, демократія, загальне виборче право, право голосу, громадянство, націєбудівниитво, національна безпека, популізм, нестабільність.

Тимчишин Богдан Владимирович студент магистратуры, Харьковский национальный университет имени В. Н. Каразина, площадь Свободы, 4, Харьков, 61022, sonicofan@ukr.net, https://orcid.org/0000-0001-7469-7339 


\section{ТОТАЛЬНАЯ ИНКЛЮЗИВНОСТЬ В ДЕМОКРАТИИ КАК ПРОБЛЕМА ПОЛИТИЧЕСКОГО РАЗВИТИЯ}

Победив в конкурентной борьбе глобальный сочиилизм, либерализм и демократия, доказали свое превосходство. Избавившись от очевидных внешних угроз, внутриполитические вызовы начали приобретать все большее значение. Под внутренними факторами понимаются как проблемь каждого отдельного демократического общества, так и проблемы конщептуального понимания либеральной демократии в современном контексте.

Утверждается, что популизм в последние 5 лет стал самой опасной проблемой в ряде молодых и зрелых демократий. Популистская риторика политиков направлена на ту часть электората, которой присущи невежество и желание услышать быстрые решения сложных системных проблем. Это особенно опасно для обществ, в которых еще не сформирована политическая нация, которая только начинает делать свои первые шаги к собственной институциионализации и поэтому требует внимания и конкретных действий со стороны ответственного гражданского общества.

Обострение хронических проблем общества остаются без внимания многих влиятельных политиков, политизация всего, что раньше принадлежало сфере частного, поляризация и популизм - никоим образом не влияют на укрепление либеральной демократии $и$ однородности общества.

Решается задача выработки комплексных решений новых вызовов современности, в частности потребности понять, какую цену общества платят за догматическую веру в перманентность либерализации демократического процесса и инклюзии различных групп. Отмечается необходимость адаптаици структур либеральной демократии $к$ новым условиям сложившейся современной политической реальности с иелью сохранения политической безопасности. Предлагается прагматично посмотреть на положение дел современного либерализма.

Ключевые слова: либерализм, демократия, всеобщее избирательное право, право голоса, гражданство, начиостроительство, начиональная безопасность, популизм, нестабильность.

The growing popularity of the ideology of liberalism in Western Europe during the Enlightenment led to the irreversible process of involving an increasing number of different interest groups in the active political life of society, the old monarchical regimes simply could not respond to growing demands, and the movement towards the establishment of broad democracy became increasingly inevitable over time. After a series of brutal revolutions and uprisings, bloody world wars, and most importantly, the Cold War, when totalitarian socialist regimes (or as they called themselves «people's democracies») completely compromised themselves, favorable conditions developed for the establishment of genuine democracy on the European continent.

And democracies in the former socialist camp were established in the euphoria of the overwhelming victory of liberalism and democracy, ignoring past historical experience of their political systems.

Today, liberal democracy is the modus in which most modern European states reside. And this is no accident, since the most economically and politically (in the sense of the absence of strong social upheavals, the effectiveness of the political system) successful countries are democracies (the USA, Great Britain, Germany, France, etc.). Countries lagging behind in development try to copy their experience in order to stabilize their own political situation, create conditions for economic growth and create an attractive image for Western countries (attracting investment, simplifying communications, gaining trust).

Over the past 30 years, a growing number of countries in Europe and the world are adapting liberal democracy as a way of making public decisions and an environment of peaceful coexistence and competition. This trend can only speak about the undeniable advantages of this system; one should not draw hasty conclusions, but pay attention to experience, especially the past 5 years.

The purpose of this article is to consider the proposal to restrict certain social groups in their participation in the democratic process, to the extent that it can help modern democracies and to review relevant practices of restriction that have already happened in the real world, to evaluate their positive and negative results in achieving a higher quality level of democracy. 
How can we change the rules of the democratic process to reduce the likelihood of implementing harmful policies for society in the short and long term? When can the participation of the broad inclusion of people become unfit or inappropriate for a particular society, in one or another historical period? When does inclusivity need to give way to pragmatism? What are the criteria for a pragmatic democratic system?

The following people studied the problems of people's wide participation in democracy and universal suffrage of varying degrees and form: Jason Brennan, Caleb Crain, Gordon Graham, Claudio López-Guerra, Konstantin Yanovsky, Sergey Zhavoronkov.

In order to better understand the subject and identify the essence of the problem, we need to carry out a detailed review.

So what are the key characteristics of liberal democracy?

Among those relevant for our study, we distinguish the following:

- wide representation of various interests, the preferred environment for societies characterized by a high degree of heterogeneity;

- softening of the principle «the winner gets everything», the policy of compromises, allows the minority not to be ignored;

- operating only within the framework of strictly formal legislation (rule of law);

- the dissipation of power among many actors causes very difficult barriers to usurpation of power by political adventurists;

- equality of voice regardless of the background and current social status.

Different forms of public order and public decision-making systems are, in a sense, similar to video games, because they have different requirements for stable operation. Autocracies, dictatorships, dysfunctional democracies (which only look like democracies) are the most common forms, since most societies cannot boast of any achievements in social progress, so they have to do with what they have, permanently or temporarily.

On the other hand, liberal democracy is one of the most demanding of the institutional configuration; for its full functioning it needs:

- influential civil society;

- working mechanisms to ensure fair competition in the political market and the market of ideas;

- the presence of independent platforms for opinions, freedom of thought and conscience;

- pluralism of political life, a balance between interest groups;

- universal suffrage;
- a high level of political education of actors.

The last two requirements, in our opinion, are the most critical, because the growing mass of the electorate bases its decisions not on critical reflection, not even on its modest intellectual capital, but on random impulses from outside or even emotions. This can stagger and endanger society, even with very rich experience in the liberal tradition.

Therefore, this work will focus primarily on finding a solution to the problem of the influence of uninformed or just outright arrogant individuals on the democratic process.

The degree of challenges varies in societies with different levels of implementation of democratic institutions.

In a society in which liberal democracy has established itself, it will be possible to observe episodic failures $\left(\right.$ glitch $\left.^{1}\right)$ in its work, of varying degrees of harm, but if a society does not fit the requirements at all, then it is likely that such a society will be plunged into a large-scale sociopolitical crisis $\left(\mathrm{crash}^{2}\right)$.

Can we trust other people in their level of rationality and responsibility for their political behavior?

Insufficient awareness or playing on emotions coupled with the ignorance of the masses about the principles of work of the highest state organizations - Ukraine.

Ukraine resumed its political independence in 1991 and chose democracy, but in view of the lack of sufficient experience of statehood and democratic traditions, such a decisionmaking system turned out to be a double-edged sword.

Ukraine immediately started with democracy, and did not come to it through political evolution. As a result, an inverted development model arises for which there are no clear guides.

Democracy has become the core element of political discourse. In theory, formally reinforced liberal democracy in building a new nation is a great achievement. However, everything is different, in cases where such democracy has not yet managed to be

\footnotetext{
${ }^{1}$ Glitch -malfunction of computer software caused by flaws in program's code or hardware damage, can be short or permanent, minor or critical.

2 Crash - complete halt of computer program or operation system, usually entails partial or entire loss of information of last session, sometimes makes impossible for further usage of computer system so software reinstallation and data recovery is required. «BSOD» are the most famous example of computer crash.
} 
institutionalized in the mass consciousness, in other words, when the subjects of the political process do not have an understanding and knowledge of how to use it correctly.

There are probably thousands of possible reasons why Ukrainians do not know how healthy democracy works, but in our opinion one of the most obvious ones is the legacy of the Soviet political culture.

The generation of Ukrainians who chose Ukraine freedom from communism was brought up on this very communism and continued to preserve the values and habits of Soviet political culture. This explains the victory of the self-proclaimed leader of the new Ukrainian independence L. Kravchuk, who allegedly led a new, already post-Soviet political community, but before that he was a former communist party careerist over V. Chernovol, a dissident who had devoted his life to the struggle for the Ukrainian national state, who had paid more than once for this with his own freedom.

At the time of the resumption of independence of Ukraine, the intellectual and academic environment did not generate enough popular political philosophers and historians of the Ukrainian nation to create a single portrait of a modern Ukrainian in the mass consciousness of the political class and society as a whole. No more or less coherent concept of the Ukrainian political nation was proposed, which would have the same values, views and goals of a small and large scale; its version of the story, which would create order in the collective memory and synchronize the events of the Ukrainian past with real-time processes, explaining what is happening. The result was fragmented masses and uninterested national political forces that use the most primitive populism in order to gain power for their own enrichment.

The incompetence of a political actor inevitably entails a lack of understanding of responsibility for decisions and actions taken in the political field. As noted by political analysts Chystilina Tatyana and Ukrainets Olena, the political irresponsibility of the Ukrainian electorate, for the most part, based on negative emotions towards specific politicians and the political elite as a whole, creates the conditions in which an «electoral revolution» occurs in every election. Such revolutions openly do not allow the continuity of a single political course of the country, which in turn becomes a serious obstacle to the political development and maturation of the Ukrainian nation (Чистіліна, Українець 2019).
Therefore, post-Soviet Ukraine, due to liberal democracy, instead of active national and state building, got 22 years of trampling on the spot, caused by «pulling the blankets» between the west and east of the country.

The personalities who contributed most to the resumption of Ukrainian independence focused mainly on the creation of a new Ukrainian state, ignoring the issue of forming the main subject in this new structure. We are talking about the Ukrainian political nation.

Ukraine is the most revealing case of how liberal democracy and universal suffrage in an immature society can cause a catastrophe. However, no matter how counterintuitive it may seem, serious problems can arise in countries with a rich democratic history.

Nevertheless, the problems caused by the system of general suffrage become a serious stick in the wheels, not only in young democracies, but also in the most long-lived ones. The increasing polarization of society, the irreconcilable systemic antagonism of the sides of the ideological spectrum, the narrowing of the space for a constructive compromise - these words can describe the current conditions in the American political system.

The United States, a practical, invulnerable bastion of liberal philosophy from the moment its independence was declared, has proved that a society based on liberal values is able to withstand the most difficult challenges, be it the spread of communism or fascism, world wars or world economic crises. However, recently, with the naked eye, one can observe the erosion of these very institutions. Populism, like a plague, swept the political space of United States of America. Based on facts of the real world, such as the growing inequality of different social strata, populism distorts them for convenient use in their own narrative. Attracting attention with loud statements, whether it is about the need to establish justice by distributing or expropriating property, it makes people who are destitute (and often instills imaginary deprivation) believe in the false sources of problems, therefore, make wrong or even harmful conclusions on methods for solving these or other problems.

The populists are playing a very dangerous game, which they can «today» win an advantage over more balanced competitors, but as a result, the whole nation will lose «tomorrow».

The principle «après moi le déluge» used in everyday speech can indicate a low level of preparation for political activity of the elites, lack of ability to think on the scale of an entire 
nation, a very short prognostic horizon, alienation of elites from the masses, asymmetry of values / interests and growing nihilism in the public mood, which is actively poured into the plane of public policy.

Along with populism, in the US the polarization of society in the political spectrum is intensifying on a number of issues (Pew Research Center 2014). This means that competing camps are moving away from each other, the number of areas in which one could have a constructive conversation narrowing down to an intermediate solution that would satisfy everyone, but not completely and the centrist position, instead of the least radical one, turns into a «choice of cowards or undecided». Because of stubbornness and ignorance, society is torn apart from within, values are becoming radical, and people begin to speak mutually incomprehensible and mutually unacceptable languages.

Thus, such harmful trends may adversely affect the quality and stability of the democratic process in the long term in this country.

In such conditions, liberal democracy is an amplifier of systemic problems, which ultimately may lead to social collapse, unless of course measures are taken to counter negative socio-political processes (such as populism), to smooth out the damage already caused to the social fabric of society, its human capital.

Are there solutions for cases when liberal democracy begins to work to the detriment of society?

In order to prevent such negative trends, various countries have taken measures to limit the participation of certain social groups in the democratic process. We will look at a successful example from the real world Latvia.

During the stay of Latvia as part of the USSR in the form of the Latvian SSR, active intra-union migration took place on the territory of Latvia, which greatly changed its demographic composition. At the time of Latvia's independence, there were a significant number of former Soviet citizens who had no deep historical connection with the country, were representatives of other ethnic groups and cultures, and speakers of other languages. The new Latvian political elites have noticed a future problem in this situation, which could complicate the country's modernization and its movement towards NATO and the EU. Thus, «non-citizens» were invented (not to be confused with «stateless persons»). «Noncitizens» is a unique legal category, which approximately corresponds to «residence» in content, its most interesting feature is its inability to influence state and political affairs, in other words, there is no voting right and the right to be elected. There are also a number of restrictions on the availability of service in state structures and bodies (judging, police, border guards, army, etc.).

The Latvian leadership, with the help of this unique institute, implemented a preventive measure to weaken the external influence on country's internal political processes. There were probably concerns that the Russian Federation would be able to manipulate the Russian-speaking part of the population in order to prevent Latvia from integrating into the EU and NATO structures.

But in our opinion, this decision contributes to the homogenization of the Latvian nation. To obtain citizenship, you need to go through a simple naturalization (knowledge of the language, history, laws, etc.) (Получение гражданства Латвии). Thus, the percentage of non-citizens decreased from the original $29 \%$ in 1995 to $11 \%$ in 2018 (Натурализация 2018). Persistent, and sometimes even openly hostile to Latvian society, individuals remained outside the political system.

Thus, Latvia was able to protect its political system from the instability of the political «swings» that occurred in Ukraine, thereby initiating the transition of the economy to market rails, creating convenient conditions for free economic activity and entrepreneurship, and preventing the development of the proRussian foreign policy vector.

Researchers Yanovsky M. and Zhavoronkov $\mathrm{S}$. came to the conclusion that, by restricting suffrage, cutting off a large part of the leftist public in Latvia and Estonia, contributed to the successful implementation of market reforms (which is a great achievement in comparison to other countries of the former USSR), the establishment of working mechanisms for protecting property and political stability (Яновский, Жаворонков 2017: 7, 11-13).

Therefore, we come to this conclusion: liberal democracy in young societies can be counterproductive, being a serious brake on the development of such societies.

When designing a new political nation, attention should be paid to the architecture of public institutions. It should be based on the real state and characteristics of the targeted society, objectively evaluate the effectiveness of the measures and tools used. Starting from the ideal hypothetical model, this often means thinking in the regime of "wishful thinking», dooming society to the failure of modernization 
and the frustration provoked by the perfectionism of public engineers.

One must not be afraid to cast aside Western universalism in state and national construction. A universal (or liberal) model of development is for everyone an accessible configuration of public institutions, but at the same time it's a for no one. It is possible to create a viable and relatively politically stable society with a developed economic system, such a society will most likely be made up of many heterogeneous fragments with a lack of sufficient and relevant historical experience of coexistence, which means it will be deprived of national identity and it will be very difficult for such a society to respond to external or existential challenges.

Stop taking voting rights for granted. The opportunity to participate in the election process, like the right to drive a vehicle or a license to carry out certain labor activities, must be confirmed by the minimum necessary knowledge and competencies.

Socrates, the philosopher of ancient Greece, was skeptical of democracy because he believed that making a competent choice (especially political) is a skill that needs to be constantly improved, and not something that can be solved by feelings or guesses. He only admitted that only knowledgeable and erudite people can have a voice in making decisions regarding political structure and life, since demagogues can take advantage of ignorance and credulity, spoiling the quality of the democratic process. Citing parallels as a captain on a ship and a statesman, Socrates focuses on the fact that a person who is involved in an important business in an area (especially a state one) should have a fairly good amount of knowledge and the level of skills necessary to complete the work (Ксенофонт).

The legitimacy of the above argument is added by the fact that even one of the main thinkers of the ideology of liberalism, namely, John Stuart Mill, was openly against inclusive participation in the democratic system. Granting the right to vote to all citizens, in Mill's view, can pose serious dangers to democracy itself. One of such dangers is the decision-making on the budget of a country where citizens with a voice, but not sufficient funds to pay taxes, will demand with their voice an increase in government spending on various benefits, explaining that this will supposedly benefit the whole society. And the very fact of the participation of people who do not pay taxes in matters of redistribution of funds is fundamentally unfair. Concerning the competence of voters, Mill saw a compromise in the form of providing more weight (specifically, the number of votes available) to the votes of people more literate and educated in a democratic system of common suffrage of multiple voting. Mill in general was distrustful of extreme or «pure» systems for making public decisions; in this respect, he can be attributed to critics of liberal democracy (Mill 1867: 68-91).

There are various points of view on how to get out of the situation of incompetence of actors, for example: voluntary renunciation of one's own right to vote in exchange for specific benefits (Базив 2018), creation of a national network of civic education among the population on the example of the European model (Топалова, Чистилина 2018). But our position is that the right to vote should be perceived as an option not to be pushed towards, but only the individual must decide how much he needs it and whether he is ready to demonstrate a sufficient level of knowledge to make the most rational choice in the democratic process.

But speaking about the conditions of social and technical development, we offer to pass an exam for obtaining the right to vote. The exam format should be similar to the American SAT Reasoning Test. The reason we chose this particular exam is because it is passed by graduates of American schools, which means that its format and content will be accessible to anyone who has reached the age of majority, that is, voting rights in the Ukrainian electoral system, but most importantly, this test evaluates cognitive and analytical human abilities, that is, they can well approach the assessment of the rationality of choice, its literacy in politics, economics, law and the media.

When accepting citizenship, each individual has the right to choose: to refuse the possibility of voting or pass the exam for «civil competence» and, if the minimum threshold is overcome, the right to participate in elections and the opportunity to be elected for 5 years will be granted in order to extend the right to retake the exam. For people who want to take a position in the state structure, the threshold is much higher than for everyone and the exam is held publicly with live audio and video recording.

The proposed filtering system can significantly reduce the emergence of populist forces and their influence on the political process, while the quality of choice will increase significantly, since a significant part of people who do not take politics seriously enough will be cut off. The system looks very exclusive, on the other hand, such a system 
opens the way to inclusiveness only through a qualitative transformation - the development of citizens' competence.

Civil competence is a complex of economic, political, historical, legal and media literacy.

Political literacy is an understanding of the work of formal and informal political processes, the principles of the decision-making system, the structure and operation of the political system.

Economic literacy - at its core lies «Economy 101», an understanding of budgeting of the economy, especially the national economy, taxation. When writing an exam, the use of the word «free» can be a good reason to annul the result, since in our opinion the use of the term «free» can very likely indicate that a person does not understand how the national budget functions, ignorance of the sources of its replenishment and borders of allowable expenses.

Historical literacy is knowledge and an ability to explain key events in the history of a country / nation.

Legal literacy is knowledge and understanding of the Constitution of Ukraine and other laws, awareness of their rights and freedoms, as well as obligations as a citizen.

Media literacy is the ability to distinguish between true and false information in the media.

This concept can be developed for a very long time and is more suitable for a separate study.

In the meantime, the example of Latvia mentioned earlier in the work proves that the establishment of barriers to participation in the democratic process, excluding incompetent social groups, can benefit not only those who have the right to vote, but the whole society and the country as a whole.

The problems of liberal democracy are systemic in nature, each country with such a decision-making system acquires its own nature of problems, therefore, it is not possible to reveal the importance of the shortcomings and vulnerabilities of liberal democracy in one article, and therefore this topic, in view of its relevance, necessarily deserves further study.

\section{REFERENCES}

Чистіліна Т., Українець О. 2019. “Безвідповідальність українських виборців: витоки та наслідки" Аналітичний центр Обсерваторія демократіï. URL: https://hvylya.net/analytics/society /bezvidpovidalnist-ukrainskih-viborciv-vitoki-tanaslidki.html
"Political Polarization in the American Public", Pew Research Center 2014. URL: https://www.peoplepress.org/2014/06/12/political-polarization-in-theamerican-public/

"Получение гражданства Латвии в порядке натурализации”, latvijas Republikas iekšlietu ministrijas pilson̄̄bas un migrācijas lietu pārvalde. URL: https://www.pmlp.gov.lv/ru/home-ru/uslugi/ grazhdanstvo/приобретение-гражданства/naturali-zacziya/

"Натурализация", Министерство иностранных дел Латвийской Республики. 2018. URL: https://www.mfa.gov.lv/ru/novosti/integraciyaobshestva-v-latvii/naturalizaciya

Яновский, М., Жаворонков, С. 2017. “Существует ли реальная альтернатива всеобщей избирательной привилегии? Балтийский путь 1992 из ловушки (Is the Taxpayers' Democracy Still Feasible Option? 1992 Experience of Escape from Universal Suffrage)". SSRN. URL: https://ssrn.com/abstract=3077963

Ксенофонт. Воспоминания о Сократе; пер с др. греч. С. И. Соболевского. Книга III URL: http://ancientrome.ru/antlitr/t.htm? $\mathrm{a}=1348105300$

Mill, J. 1867. Considerations on Representative Government. London.

Базив, Д. 2018. Как истребить популистов? ZN,UA URL: https://zn.ua/internal/kak-istrebitpopulistov-299798_.html

Топалова, С., Чистилина, Т. 2018. “Будущее гражданского образования в Украине - переход к актуальной европейской модели" Аналитический иентр Обсерватория демократии. URL: https://hvylya.net/analytics/society/budushheegrazhdanskogo-obrazovaniya-v-ukraine-perehod-kaktualnoy-evropeyskoy-modeli.html

\section{REFERENCES}

Chystilina T., Ukrayinets O. 2019. "Irresponsibility of Ukrainian voters: origins and consequences" Center for Political Analysis "Observatory of Democracy". URL: https://hvylya.net/analytics/society/ bezvidpovidalnist-ukrainskih-viborciv-vitoki-tanaslidki.html (in Ukrainian).

"Political Polarization in the American Public", Pew Research Center 2014. URL: https://www.peoplepress.org/2014/06/12/political-polarization-in-theamerican-public/

"Obtaining Latvian citizenship by naturalization", LATVIJAS REPUBLIKAS IEKŠLIETU MINISTRIJAS

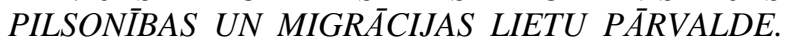
URL: https://www.pmlp.gov.lv/ru/home-ru/uslugi/ grazhdanstvo/приобретение-гражданства /naturalizacziya/_(in Russian).

"Naturalization", Ministry of Foreign Affairs of the Republic of Latvia. 2018. URL: https://www.mfa.gov.lv/ru/novosti/integraciyaobshestva-v-latvii/naturalizaciya (in Russian).

Yanovskyi M. Zhavoronkov S. 2017. "Is there a real alternative to universal suffrage? 1992 Baltic Way out of the trap (Is the Taxpayers' Democracy Still Feasible Option? 1992 Experience of Escape from Universal Suffrage)". SSRN. URL: https://ssrn.com/abstract=3077963 (in Russian). 


\title{
Вісник ХНУ імені В. Н. Каразіна, серія «Питання політологї̈,, вип. 35, 2019
}

Ksenofont. Memories of Socrates; пер с др. греч. С. И. Соболевского. Book III URL: http://ancientrome.ru/antlitr/t.htm? $\mathrm{a}=1348105300 \quad$ (in Russian).

Mill, J. 1867. Considerations on Representative Government. London.

Bazyv D. 2018. "How to exterminate the populists?" ZN,UA URL: https://zn.ua/internal/kakistrebit-populistov-299798_.html (in Russian).
Topalova S. Chystylyna T. 2018. "The future of civic education in Ukraine - the transition to the current European model" Center for Political Analysis "Observatory of Democracy". URL: https://hvylya.net/analytics/society/budushheegrazhdanskogo-obrazovaniya-v-ukraine-perehod-kaktualnoy-evropeyskoy-modeli.html (in Ukrainian).

DOI: $10.26565 / 2220-8089-2019-35-04$

УДК $321.352 / 354$

\author{
Божко Павло Андрійович \\ аспірант кафедри політології, \\ Харківський національний, \\ університет імені В.Н. Каразіна, \\ майдан Свободи, 4, Харків, 61022, \\ bozhko.pavel.95@gmail.com, \\ https://orcid.org/0000-0003-0216-1783
}

\section{МОДЕЛІ ТА КОНЦЕПЦІЇ МОДЕРНІЗАЦІЇ ДЕРЖАВНОГО УПРАВЛІННЯ}

Модернізація змінюе основні иільові, функиіональні, структурні принциипи побудови державного управління, тим самим відбувається парадигмальний зсув у розумінні його місия $i$ місії у відносинах держсва-ринок-громадянське суспільство. До старої парадигми відноситься бюрократична модель держсавного управління, до нової парадигми - моделі нового державного управління та мережева.

Ці моделі суперечливо переплітаються в умовах впливу глобалізащії та децентралізащії на модернізаційні прочеси в державному управлінні, що створює нові проблеми адаптаціі адміністративних ієрархій (бюрократії) до глобальних викликів і вимог деволючії. Виникає завдання інтеграції нових горизонтальних зв'язків (мереж) в традииійні вертикальні структури. Одночасно загострюється проблема здатності держави підвищувати ефективність дій чиновників в умовах швидкої трансформації навколишнього середовища. Крім того, існує традиційна для державного управління проблема масштабу, тобто відповідності функиій і ресурсів на різних управлінських рівнях характеру і обсягу наявних завдань. Розв'язання изих проблем на етапі транзиту багато в чому залежсть від характеру інституиійних траєкторій $і$ стратегій реформ, щио виникають, їхньої орієнтованості на збереження балансу стабільності і змін, заснованого на досвіді попередніх перетворень. Пріоритетна для багатьох реформаторів менеджеріальна модель 3 ï неминучою децентралізацією, здійснюваною в інституційному середовищі, щзо не досягло необхідного рівня самоорганізації $і$ підзвітності, очевидно призведе до прогресуючої втрати державною бюрократією автономії від спеціальних груп інтересів. Посилення ролі неформальних управлінських практик в умовах не сформованих норм адміністративної етики не забезпечить незаангажованого безособового правозастосування.

Однак критика нового державного управління не робить обгрунтованим вибір бюрократичної або мережевої моделей. Пріоритет має не вибір тієї або іншої теоретичної моделі модернізаиії як ї̈ мети, а самий прочес розробки політики ї̈ проведення. Критерій керованості, що відображає розвиненість модернізаиійних здібностей державного управління дає орієнтири інституиійного будівниитва.

Ключові слова: модернізачія, державне управління, бюрократична модель державного управління, модель нового державного управління, мережева модель.

(C) Божко П.А., 2019. 